\title{
Icelandic Chronicle
}

\section{João Vicente Ganzarolli de Oliveira*}

Professor and Researcher of the Tércio Pacitti Institute of the Federal University of Rio de Janeiro, Brazil

*Corresponding Author: João Vicente Ganzarolli de Oliveira, Professor and Researcher of the Tércio Pacitti Institute of the Federal U niversity of Rio de Janeiro, Brazil.

Received: June 05, 2019; Published: August 06, 2019

DOI: 10.31080/ASAG.2019.03.0599

\section{Abstract}

At least three reasons make Iceland a fascinating country: its nature, its history and its people. The following lines are based on personal impressions gathered during my stay in Iceland, in the year 2013. Special emphasis is laid on geographical factors, as well as on cultural circumstances.

Keywords: Iceland; Geology; Geography; History; Culture

People are always asking me about eskimos, but there are no eskimos in Ic Bijördk

\section{Half in America, half in Europe}

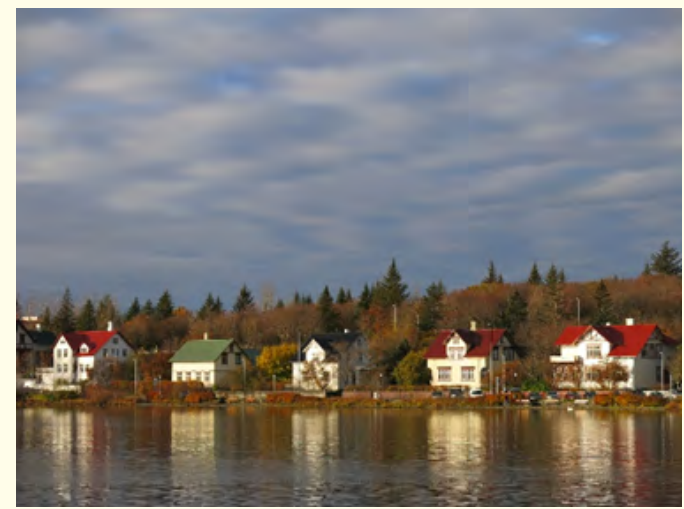

Figure 1: Reykjavík (Photo taken by the Author)

E15 was the abbreviation established by the press for the Icelandic volcano Eyjafjallajökull, when it erupted in the year 2010, given the near impossibility of pronouncing properly that sixteen-letter word $(E+15)$ for those who do not speak the language of Iceland. Its uniqueness and richness seem to mirror the very society that speaks it. Descending from the old Norwegian (gammelnorsk), the Icelandic is a member of the family of the northern Germanic languages, and is part of the cultural legacy of the Vikings' era (793 to 1066). During that period, the Vikings - a
Scandinavian people who used sail the rivers and seas of Europe, in order to raid and trade - settled in Iceland, the Faroe Islands, Normandy, England, Ireland, Scotland, Sicily, the Baltic Sea, Russia, Greece and in Anatolia (which is already a part of Asia). They also reached Greenland and Canada; it is believed that Leif Erikson (c. 970 - c. 1020), the Norse explorer who landed in the American continent five hundred years before Christopher Columbus (14511506), was born in Iceland. Crossed by the 66th parallel, just as if it was trying to enter the Arctic Circle, Iceland, literally an icy land, is the youngest geological portion of Europe [1]: it emerged tectonically in the form of a volcanic island about 20 million years ago, which means little more than that a blink of an eye if compared with the age of the Earth, which amounts to c. 4,6 billion years [2]. In addition to being located at the junction between the North Atlantic and the Arctic Oceans, Iceland belongs to the Mid-Atlantic Ridge, which separates the American and Euro-Asian Plates and has an average spreading rate of a few centimetres per year. Nearly half of its territory is on the North-American Plate; geologically speaking, Reykjavík, Iceland's capital and home to almost half of its population (c. 350,000 in total), is an American city.

More than twice as big as Denmark (with the exception of gigantic Greenland, of course), but more than half smaller than Norway, Iceland is a vast basaltic plateau, $10 \%$ of which covered by glaciers. Such a small population spread through less than 40,000 sq mi of land mass makes of Iceland the most sparsely populated country in 
Europe. Demographically speaking, Iceland is also very young by European standards. Its earliest settlement dates back to $870 \mathrm{AD}$ and is often attributed to Vikings of Swedish origin. It is known, however, that Celtic monks from Ireland or Scotland arrived in Iceland a century and a half before. It is presumed that the Irish monk and saint Brendan (c. 484 - c. 577) at least caught sight of the coastline of Iceland during his quest for the Terrestrial Paradise. Saint Brendan also sought the island Bresail (in Old Irish: "land of the blessed ones"), which ended up being shown in more than one medieval map. Such is the origin of the word "Brazil", name of the largest country in South America and the fifth largest in the world, discovered by the Portuguese Pedro Álvares Cabral (c. 1467 - 1520) in 1500 [3]. The fact is that Cabral and the other great navigators of the Modern Era owe more to the Irish Saint Brendan than to the Viking Leif Erikson (whose exploits left no important cultural traces in what became the New World), since they knew, at least by hearing, the content of the Navigatio, an anonymous work written by a Celtic monk in the $11^{\text {th }}$ century, in which Saint Brendan's deeds are described; it is not impossible that he has landed in America, preceding this way Christopher Columbus's voyage by roughly one thousand years [4]. As an inspirer of the Great Discoveries, Saint Brendan matches in importance names like those of the Venetian Marco Polo (1254-1324) and of the British Sir John Mandeville (name attributed to the author of a famous travel memoir which first circulated in Europe during the second half of the $14^{\text {th }}$ century).

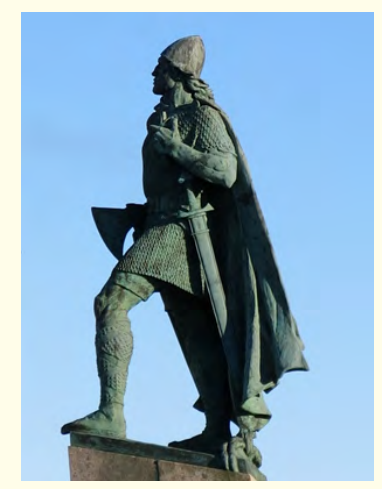

Figure 2: Leif Erikson facing West, designed by the American Sculptor Alexander Stirling Calder (1870-1945)

(Photo taken by the Author)

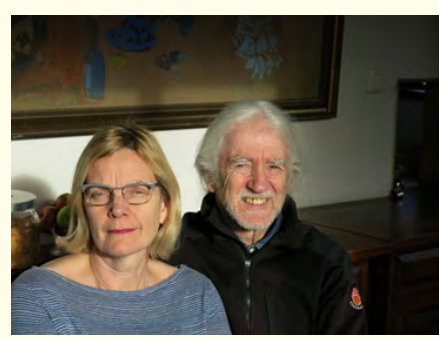

Figure 3: Edda and Rúnar, Icelanders

(Photo taken by the Author)
Who are they, the Icelanders?

Roughly speaking, Icelanders may be considered as an ethnic mixture of Scandinavians and Celts. In 930, Iceland became the first country in the world to adopt democratic parliamentarism a political heritage of Greek origin and developed alongside with Christianity, which, based on the extremely rare virtue of selfcriticism, grants equality of rights and duties to all members of a society [5]; significantly, this occurred in the Pingvellir valley, on the crest of the mid-ocean ridge - a geological peculiarity that allows, being in Pingvellir, to cross on foot from America to Europe and vice versa. During almost seven hundred years (between 1262 and 1918), Iceland remained annexed to Norway, Denmark or both, who came to constitute a single kingdom. Autonomy came in 1918 and total independence in 1945. Icelandic economy relies mainly on agriculture, fishing and metallurgical industry [6]. Economical and social problems are minimal compared to those of the outside world; the country has no armed forces and its police is almost symbolic, since crime practically does not exist in the island. Reykjavík is perhaps the safest capital in the world.

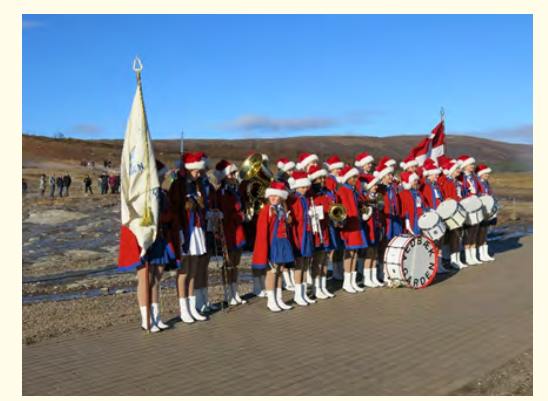

Figure 4: Somewhere on the the Mid-Atlantic Ridge (Photo taken by the Author)

Iceland, a place where geological facts happen before our very eyes, is also suitable for cultural growth. Music, cinema, architecture, sculpture and painting have their place in Icelandic society, but literature is supreme. The island is home to a rich literary assortment of mainly Scandinavian origin, which was firstly put down in written form between the 12th and the 13th centuries. We are talking about the sagas, literary genre that many see as the ancestor of novels and that turned Iceland into the cultural capital of the Scandinavian world in the Late Middle Ages. Geographical isolation seems to have functioned as an advantage: far from everything and everybody, Icelanders have endeavoured to preserve their oral collection of poetry (notably the Edda, attributed to the Icelandic historian, poet, and politician Snorri Sturlason [11791241], consisting mainly of poems in homage to Germanic heroes and gods), legends, short stories and so on; great distance from the European continent and long winter nights favoured the development of the habit of reading, which left permanent marks in Icelandic culture: until today, Icelanders read (the country has a literacy rare rate is of 100\%) and write a lot. In 1955, the Literature Nobel was given to the Icelandic Halldór Laxness (1902-98). Indeed, “Ice- 
landers are avid consumers of literature, with the highest number of bookstores per capita in the world. For its size, Iceland imports and translates more international literature than any other nation. Iceland also has the highest per capita publication of books and magazines, and around $10 \%$ of the population will publish a book in their lifetimes. Most books in Iceland are sold between late September to early November. This time period is known as Jolabokaflod, the Christmas Book Flood. The Flood begins with the Iceland Publisher's Association distributing Bokatidindi, a catalogue of all new publications, free to each Icelandic home" [7].

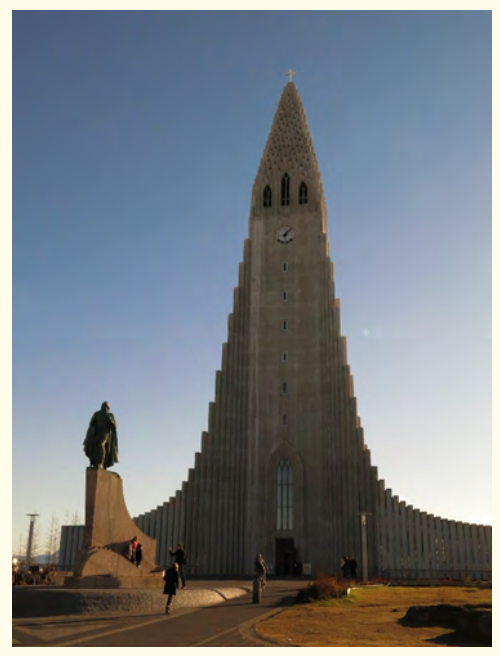

Figure 5: Resembling Iceland's geological features, Hallgrímskirkja is the largest church in the country

(Photo taken by the Author)

Christianity came to Iceland around the year 1000 . Nordic paganism did not die out; it remains alive until the present; there is a widespread belief in ghosts, mythological beings (gnomes, trolls, etc.) and "hidden people" (huldfólk). Rarely do Icelanders talk about this matter with foreigners, which is a typical trait of a centripetal culture, so to say. Nowadays, "Iceland is a very secular country; as with other Nordic nations, religious attendance is relatively low. The above statistics represent administrative membership of religious organisations, which does not necessarily reflect the belief demographics of the population. According to a study published in $2001,23 \%$ of the inhabitants were either atheist or agnostic. A Gallup poll conducted in 2012 found that $57 \%$ of Icelanders considered themselves "religious", 31\% considered themselves "nonreligious", while $10 \%$ defined themselves as "convinced atheists", placing Iceland among the ten countries with the highest proportions of atheists in the world. The proportion registered in the official Church of Iceland is declining rapidly, more than $1 \%$ per year (the Church of Iceland has declined from $80 \%$ in 2010 to less than 70\% in 2017)" [8].

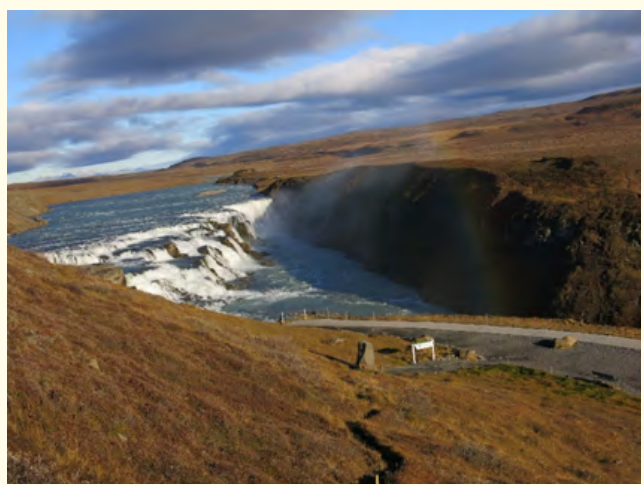

Figure 6: Gullfoss, one of Iceland's geological wonders (Photo taken by the Author)

\section{Plunging into the unknown}

Like all islands, and especially those too far away from the continents, Iceland naturally tends to promote the preservation of the biological traits of their inhabitants. (Part of Australia's Mesozoic fauna exists to this day.) The same applies to culture, as it is manifest in the already mentioned Icelandic neo-paganism. Like the deserts, islands are constantly inspiring the creation of imaginary worlds, places that came to existence in literature and its ramifications (theatre, movie etc.).

\section{Conclusion}

Those are places where things are not what they seem and whose difficulty to be mapped leaves us with no easy answer concerning their concrete existence [9]. What is out there, beyond that mountain, that valley, that river, that ocean? Such is the kind of question that motivated Vikings like Leif Erikson, Genoese like Christopher Columbus, Portuguese like Pedro Álvares Cabral and, long before them, Celtics like Saint Brendan to plunge boldly into the unknown.

\section{Bibliography}

1. "The Sagas of Icelanders say that a Norwegian named Naddodd (or Naddador) was the first Norseman to reach Iceland, and in the 9th century he named it Snæland Snæland or 'snow land' because it was snowing. Following Naddodd, the Swede Garðar Svavarsson arrived, and so the island was then called Garðarshólmur, which means 'Garðar's Isle'. Then came a Viking named Flóki Vilgerðarson; his daughter drowned en route, then his livestock starved to death. The sagas say that the rather despondent Flóki climbed a mountain and saw a fjord (Ísafjörður) full of icebergs, which led him to give the island its new and present name" (Andrew Evans et alii. https:// en.wikipedia.org/wiki/Iceland). 
2. The list of Icelandic volcanos "includes 130 active and extinct volcanic mountains, of which 18 have erupted since human settlement of Iceland began circa 900 AD" (T. Thordarson and G. Larsen. https://en.wikipedia.org/wiki/List_of_volcanoes_ in_Iceland).

3. See Luis Weckmann. La herencia medieval de Brasil, México, Fondo de Cultura Económica (1993): 289 and 290.

4. See Navigatio., et al. The Quest for America, Nova York/Washington/London, Praeger, (1971): 90.

5. Cf. Thomas Woods. How the Catholic Church Built Western Civilization (with a new preface from Cardinal Antonio Cañizares), Washington, Regnery History (2012): 20-21.

6. "Infertile soil, volcanic eruptions, deforestation and an unforgiving climate made for harsh life in a society where subsistence depended almost entirely on agriculture. The Black Death swept Iceland twice, first in 1402-1404 and again in 1494-1495. The former outbreak killed $50 \%$ to $60 \%$ of the population, and the latter $30 \%$ to $50 \%$. (...) Until the 20th century, Iceland relied largely on subsistence fishing and agriculture. Industrialization of the fisheries and Marshall Plan aid following World War II brought prosperity and Iceland became one of the wealthiest and most developed nations in the world. In 1994, it became a part of the European Economic Area, which further diversified the economy into sectors such as finance, biotechnology, and manufacturing" (Vala Hafstad et alii. https://en.wikipedia.org/wiki/Iceland).

7. Andrew Evans., et al. https://en.wikipedia.org/wiki/Iceland.

8. Ibid.

9. Cf Pierre Jourde. Géographies imaginaires de quelques inventeurs de mondes au XXe. siècle. Gracq, Borges, Michaux, Tolkien, Paris, José Corti (1991): 121-231.

\section{Volume 3 Issue 9 September 2019}

(C) All rights are reserved by João Vicente Ganzarolli de Oliveira. 